\title{
Kajian Pustaka Potensi Aktivitas Antibakteri Ekstrak Daun dan Biji Pepaya (Carica papaya L)
}

\section{Dinda Febryna*, Sri Peni Fitrianingsih}

Prodi Farmasi, Fakultas Matematika dan Ilmu Pengetahuan Alam, Universitas Islam Bandung, Indonesia.

*dindafeb99@gmail.com, spfitrianingsih@gmail.com

\begin{abstract}
Infectious diseases are one of the health problems in developing countries such as Indonesia. Papaya (Carica papaya L.) is a plant that is widely consumed as a food ingredient and has various potentials for treatment, one of which is antibacterial. The purpose of this literature search is to examine information about the potential antibacterial activity of papaya leaves and seeds (Carica papaya L) and to find out what compounds contain antibacterial activity. This research is a literature search using the Systematic Literature Review (SLR) method which contains national and international manuscripts. Based on the results of a literature search, papaya leaves and seeds (Carica papaya L) are able to inhibit several bacteria, namely Bacillus Subtilis, Escherichia coli, Staphylococus aureus, Pseudomonas aeruginosa, Shigella dysentriae and Salmonella typhi. Secondary metabolite compounds that act as antibacterial are alkaloids, flavonoids and tannins. The active compounds contained in papaya leaves are karpain alkaloids and tocophenols.
\end{abstract}

Keywords: antibacterial papaya leaves, antibacterial papaya seeds, antibacterial papaya extract.

\begin{abstract}
Abstrak. Penyakit infeksi menjadi salah satu masalah kesehatan di Negara berkembang seperti di Indonesia. Pepaya (Carica papaya L) merupakan tanaman yang banyak dikonsumsi sebagai bahan makanan dan memiliki beragam potensi untuk pengobatan salah satunya sebagai antibakteri. Tujuan dari penelusuran pustaka ini yaitu untuk mengkaji informasi mengenai potensi aktivitas antibakteri dari daun dan biji pepaya (Carica papaya L) dan mengetahui kandungan senyawa apa yang memiliki aktivitas antibakteri. Penelitian ini berupa penelusuran pustaka dengan metode Systematic Literature Review (SLR) yang memuat naskah nasional maupun internasional. Berdasarkan hasil penelusuran pustaka daun dan biji pepaya (Carica papaya L) mampu menghambat beberapa bakteri yaitu Bacillus Subtilis, Escherichia coli, Staphylococcus aureus, Pseudomonas aeruginosa, Shigella dysentriae, dan Salmonella typhi. Senyawa metabolit sekunder yang bersifat sebagai antibakteri yaitu alkaloid, flavonoid dan tanin. Adapun senyawa aktif yang terkandung pada daun pepaya yaitu alkaloid karpain dan tocophenol.
\end{abstract}

Kata Kunci: antibakteri daun pepaya, antibakteri biji pepaya, antibakteri ekstrak pepaya. 


\section{A. Pendahuluan}

Penyakit infeksi merupakan salah satu masalah kesehatan diberbagai negara dan menjadi penyebab kematian terbesar di dunia. Berdasarkan data The Global Health Observatory menyatakan bahwa penyakit infeksi menjadi salah satu dari 10 penyebab kematian di dunia(World Health Organization (WHO), 2020). Penyakit infeksi menjadi salah satu masalah kesehatan di Negara berkembang seperti di Indonesia. Adapun kelompok mikroorganisme patogen yang menyebabkan penyakit infeksi yaitu bakteri, virus, jamur, dan protozoa (Wadapurkar et al., 2018; Jawetz, 2005).

Pada umumnya, bakteri yang dapat menyebabkan penyakit infeksi yaitu Escherichia coli, Staphylococcus aureus, Salmonella typhi dan Shigella dysenteriae (Gillespie and Bamford, 2009; Jawetz, 2005). Staphylococcus aureus dapat menyebabkan penyakit infeksi kulit. Sedangkan bakteri Salmonella typhi dapat menyebabkan demam tifoid (Misna and Diana, 2016). Salah satu pengobatan untuk infeksi bakteri dapat dilakukan dengan pemberian antibiotik, namun adapun alternatif yang dapat digunakan untuk pengobatan penyakit infeksi yaitu dengan memanfaatkan senyawa metabolit sekunder dari suatu tanaman sebagai antibakteri (Mawan,dkk., 2017). Tanaman pepaya (Carica papaya L) dapat dijumpai diberbagai daerah di Indonesia, seluruh bagian pepaya ini dapat dimanfaatkan sebagai obat tradisional mulai dari batang, daun, bunga, buah, biji, dan akarnya (Tietze,2002). Secara tradisional tanaman pepaya (Carica papaya L) berkhasiat untuk mengatasi masalah pencernaan, sebagai sumber antioksidan, bersifat antijamur, antibakteri, antiinflamasi, penurun demam, penambah nafsu makan, dan berkhasiat terhadap penyakit malaria (Ariani, dkk 2019). Kandungan senyawa pada tanaman pepaya yang memiliki efek sebagai antibakteri diantaranya flavonoid, alkaloid, saponin, tannin, dan terpenoid.

Penelitian yang telah dilakukan oleh Karisma,E.V (2019) bahwa ekstrak etanol daun pepaya dapat menghambat pertumbuhan Escherichia coli dan Staphylococcus aureus. Sedangkan pada biji pepaya mempunyai aktivitas antibakteri terhadap Escherichia coli, Staphylococcus aureus, Pseudomonas aeruginosa, Salmonella typhi, dan Jamur Candida albicans (Torar GM, 2017). Berdasarkan latar belakang yang telah dikemukakan, dapat diperoleh rumusan masalah yaitu bagaimana potensi aktivitas antibakteri dari daun dan biji pepaya (Carica papaya L) serta dapat mengetahui kandungan senyawa apa yang memiliki aktivitas antibakteri pada daun dan biji pepaya (Carica papaya $\mathrm{L}$ ).

Adapun penelitian ini bertujuan untuk mengkaji informasi mengenai potensi aktivitas antibakteri dari daun dan biji pepaya (Carica papaya L) dan mengetahui kandungan senyawa apa yang memiliki aktivitas antibakteri. Manfaat yang dapat diperoleh dari penelitian ini diharapkan dapat memberikan informasi sebagai sumber ilmiah mengenai aktivitas antibakteri tanaman pepaya sebagai antibakteri.

\section{B. Metodologi Penelitian}

Penelitian ini dilakukan dengan metode penelusuran pustaka (systematic literature review) melalui artikel yang dipublikasin pada Jurnal Nasional maupun Jurnal Internasional. Pencarian dilakukan melalui laman pencarian seperti Google Scholar, Science Direct (Elsivier), Springer, Taylor and Francis dan PubMed. Dengan menggunakan kriteria inklusi yaitu artikel tentang aktivitas antibakteri pepaya (Carica papaya L), artikel tentang antibakteri ekstrak daun dan biji pepaya, artikel tentang potensi tanaman pepaya dan artikel yang dipublikasikan lebih dari tahun 2010. Sedangkan kriteria eksklusi yaitu artikel selain antibakteri tanaman pepaya (Carica papaya L), artikel fraksi tanaman pepaya dan artikel yang dipublikasikan kurang dari tahun 2010. 


\section{Hasil Penelitian dan Pembahasan}

Tabel 1. Hasil Aktivitas Antibakteri Ekstrak Daun dan Biji Pepaya (Carica papaya L)

\begin{tabular}{|c|c|c|c|c|c|c|}
\hline \multirow{2}{*}{$\begin{array}{l}\text { Bagian } \\
\text { tanaman }\end{array}$} & \multirow{2}{*}{$\begin{array}{l}\text { Jenis } \\
\text { ekstrak }\end{array}$} & \multirow{2}{*}{ Bakteri } & \multirow{2}{*}{ Metode uji } & \multicolumn{2}{|c|}{ Aktivitas antibakteri } & \multirow{2}{*}{ Pustaka } \\
\hline & & & & Konsentrasi & $\begin{array}{c}\text { Diameter } \\
\text { zona hambat }\end{array}$ & \\
\hline \multirow{12}{*}{ Daun Pepaya } & \multirow{2}{*}{ Etanol } & Escherichia coli & \multirow{2}{*}{$\begin{array}{l}\text { Difusi } \\
\text { Cakram }\end{array}$} & $200 \mathrm{mg} / \mathrm{mL}$ & $6,5 \mathrm{~mm}$ & \multirow{2}{*}{$\begin{array}{l}\text { Tutun } M \text {, } \\
\text { (2016). }\end{array}$} \\
\hline & & $\begin{array}{c}\text { Staphylococcus } \\
\text { aureus }\end{array}$ & & $300 \mathrm{mg} / \mathrm{mL}$ & $7,9 \mathrm{~mm}$ & \\
\hline & \multirow{2}{*}{ Etanol } & $\begin{array}{c}\text { Escherichia } \\
\text { coli }\end{array}$ & \multirow{2}{*}{$\begin{array}{c}\text { Difusi } \\
\text { Cakram }\end{array}$} & $100 \mathrm{mg} / \mathrm{mL}$ & $10,3 \mathrm{~mm}$ & \multirow{2}{*}{$\begin{array}{l}\text { Roni A,dkk } \\
\text { (2018). }\end{array}$} \\
\hline & & $\begin{array}{c}\text { Staphylococcus } \\
\text { aureus }\end{array}$ & & $100 \mathrm{mg} / \mathrm{mL}$ & $11,3 \mathrm{~mm}$ & \\
\hline & Etanol & Bacillus subtilis & $\begin{array}{l}\text { Difusi } \\
\text { cakram }\end{array}$ & $0,02 \mathrm{mg} / \mathrm{mL}$ & $8,1 \mathrm{~mm}$ & $\begin{array}{c}\text { Sudarwati } \\
\text { T.P.L, dkk } \\
\text { (2018). }\end{array}$ \\
\hline & \multirow{2}{*}{ Etanol } & $\begin{array}{c}\text { Escherichia } \\
\text { coli }\end{array}$ & \multirow{2}{*}{$\begin{array}{l}\text { Difusi } \\
\text { sumuran } \\
\text { agar }\end{array}$} & $100 \mathrm{mg} / \mathrm{mL}$ & $8,4 \mathrm{~mm}$ & \multirow{2}{*}{$\begin{array}{c}\text { Karisma, E. V. } \\
\text { (2019). }\end{array}$} \\
\hline & & $\begin{array}{c}\text { Staphylococcus } \\
\text { aureus }\end{array}$ & & $100 \mathrm{mg} / \mathrm{mL}$ & $9,4 \mathrm{~mm}$ & \\
\hline & \multirow{5}{*}{ Etanol } & Escherichia coli & \multirow{5}{*}{$\begin{array}{l}\text { Difusi } \\
\text { sumuran } \\
\text { agar }\end{array}$} & $100 \mathrm{mg} / \mathrm{mL}$ & $8 \mathrm{~mm}$ & \multirow{5}{*}{$\begin{array}{l}\text { Nirosha, N., \& } \\
\text { Mangalanayaki } \\
\text {, R. (2013). }\end{array}$} \\
\hline & & $\begin{array}{c}\text { Pseudomonas } \\
\text { aeruginosa }\end{array}$ & & $100 \mathrm{mg} / \mathrm{mL}$ & $10 \mathrm{~mm}$ & \\
\hline & & Salmonella typhi & & $100 \mathrm{mg} / \mathrm{mL}$ & $8 \mathrm{~mm}$ & \\
\hline & & $\begin{array}{c}\text { Staphylococcus } \\
\text { aureus } \\
\end{array}$ & & $100 \mathrm{mg} / \mathrm{mL}$ & $6 \mathrm{~mm}$ & \\
\hline & & Bacillus subtilis & & $100 \mathrm{mg} / \mathrm{mL}$ & $6 \mathrm{~mm}$ & \\
\hline \multirow{5}{*}{ Daun Pepaya } & \multirow{5}{*}{ etil asetat } & Escherichia coli & \multirow{5}{*}{$\begin{array}{l}\text { Difusi } \\
\text { sumuran } \\
\text { agar }\end{array}$} & $100 \mathrm{mg} / \mathrm{mL}$ & $8 \mathrm{~mm}$ & \multirow{5}{*}{$\begin{array}{l}\text { Nirosha, N., \& } \\
\text { Mangalanayaki } \\
\text {, R. (2013). }\end{array}$} \\
\hline & & $\begin{array}{c}\text { Pseudomonas } \\
\text { aeruginosa }\end{array}$ & & $100 \mathrm{mg} / \mathrm{mL}$ & $8 \mathrm{~mm}$ & \\
\hline & & Salmonella typhi & & $100 \mathrm{mg} / \mathrm{mL}$ & $6 \mathrm{~mm}$ & \\
\hline & & $\begin{array}{c}\text { Staphylococcus } \\
\text { aureus } \\
\end{array}$ & & $100 \mathrm{mg} / \mathrm{mL}$ & $6 \mathrm{~mm}$ & \\
\hline & & Bacillus subtilis & & $100 \mathrm{mg} / \mathrm{mL}$ & $8 \mathrm{~mm}$ & \\
\hline \multirow{7}{*}{ Biji Pepaya } & \multirow{2}{*}{ Etanol } & $\begin{array}{c}\text { Pseudomonas } \\
\text { aeruginosa }\end{array}$ & \multirow{2}{*}{$\begin{array}{l}\text { Difusi } \\
\text { sumuran } \\
\text { agar }\end{array}$} & $200 \mathrm{mg} / \mathrm{mL}$ & $5 \mathrm{~mm}$ & \multirow{2}{*}{$\begin{array}{l}\text { Torar, G. M. } \\
\text { (2017). }\end{array}$} \\
\hline & & $\begin{array}{c}\text { Staphylococcus } \\
\text { aureus }\end{array}$ & & $200 \mathrm{mg} / \mathrm{mL}$ & $6 \mathrm{~mm}$ & \\
\hline & Etanol & Escherichia coli & $\begin{array}{c}\text { Difusi } \\
\text { sumuran } \\
\text { agar } \\
\end{array}$ & $12,5 \mathrm{mg} / \mathrm{mL}$ & $3,6 \mathrm{~mm}$ & $\begin{array}{c}\text { Ariani, N., dkk } \\
\text { (2019). }\end{array}$ \\
\hline & Etanol & \multirow{2}{*}{$\begin{array}{l}\text { Escherichia } \\
\text { coli }\end{array}$} & \multirow{2}{*}{$\begin{array}{l}\text { Difusi } \\
\text { sumuran } \\
\text { agar }\end{array}$} & $100 \mathrm{mg} / \mathrm{mL}$ & $10,5 \mathrm{~mm}$ & \multirow{2}{*}{$\begin{array}{l}\text { Tambunan.M.L } \\
\text {., dkk (2018). }\end{array}$} \\
\hline & n-Heksan & & & $500 \mathrm{mg} / \mathrm{mL}$ & $12,1 \mathrm{~mm}$ & \\
\hline & \multirow[t]{2}{*}{ Etanol } & $\begin{array}{c}\text { Escherichia } \\
\text { coli }\end{array}$ & $\begin{array}{l}\text { Difusi } \\
\text { cakram }\end{array}$ & $100 \mathrm{mg} / \mathrm{mL}$ & $12,3 \mathrm{~mm}$ & \multirow{2}{*}{$\begin{array}{l}\text { Roni A, dkk } \\
\text { (2018). }\end{array}$} \\
\hline & & $\begin{array}{c}\text { Staphylococcus } \\
\text { aureus }\end{array}$ & kertas & $100 \mathrm{mg} / \mathrm{mL}$ & $11,3 \mathrm{~mm}$ & \\
\hline
\end{tabular}

Berdasarkan kedua bagian tanaman pepaya (Carica papaya L), ekstrak etanol pada daun dan biji pepaya menunjukkan aktivitas antibakteri terhadap bakteri Bacillus subtilis, Esherchia coli, Staphylococcus aureus, Salmonella typhi, dan Pseudomonas aeruginosa, serta terbukti dapat menghambat bakteri tersebut. Karena salah satu senyawa aktif pada daun pepaya yaitu tocophenol yang merupakan golongan senyawa fenol dan senyawa alkaloid karpain termasuk golongan alkaloid ini memiliki kemampuan sebagai antibakteri. (Tutun, M., 2016). Pada Tabel 1 menunjukkan nilai diameter zona hambat yang bervariasi, hal ini dapat 
disebabkan karena perbedaan diameter zona hambat yang dihasilkan dapat dipengaruhi oleh adanya perbedaan bahan uji, metode ekstraksi, jumlah bakteri, konsentrasi zat antibakteri, ketebalan media pertumbuhan, suhu dan waktu inkubasi (Nor, T.A., dkk. 2018; Zukhri. S, 2015).

Etanol merupakan pelarut polar yang mampu menarik senyawa kimia dalam tumbuhan yang bersifat pola, dan merupakan pelarut universal sehingga mampu menarik senyawa yang bersifat polar seperti alkaloid, flavonoid, dan tanin (Nor, 2018; Tjukup,M 2012). Etil asetat mampu menarik senyawa polar dan nonpolar, dimana mampu menarik senyawa alkaloid, flavonoid, steroid dan triterpenoid (Purba, 2001; Akbar, 2010). Sedangkan n-Heksan merupakan pelarut yang bersifat nonpolar sehingga mampu menarik senyawa yang bersifat nonpolar (Romadanu, dkk., 2014).

Tabel 2. Hasil skrining fitokimia

\begin{tabular}{|c|c|c|c|c|c|c|c|c|}
\hline \multirow{2}{*}{$\begin{array}{c}\text { Bagian Tanaman } \\
\text { Pepaya }\end{array}$} & \multicolumn{7}{|c|}{ Kandungan Senyawa } & \multirow{2}{*}{ Pustaka } \\
\hline & Alkaloid & Flavonoid & Tanin & Saponin & Kuinon & Steroid & Triterpenoid & \\
\hline Daun & + & + & + & + & + & + & + & \multirow{2}{*}{$\begin{array}{l}\text { Roni, A., } \\
\text { (2018). }\end{array}$} \\
\hline Biji & + & + & - & - & - & + & + & \\
\hline Biji & + & + & + & + & - & - & - & $\begin{array}{l}\text { Ariani, N., } \\
\text { dkk (2019). }\end{array}$ \\
\hline
\end{tabular}

Berdasarkan hasil skrining fitokimia yang dilakukan oleh Ariani, dkk (2019) biji pepaya (Carica papaya L) mengandung senyawa flavonoid, alkaloid, tanin saponin. Menurut Roni, dkk (2018) hasil skrining fitokimia dari daun pepaya (Carica papaya L) mengandung senyawa alkaloid, flavonoid, saponin, tanin, kuinon, senyawa steroid dan triterpenoid. Sedangkan pada biji pepaya mengandung alkaloid, flavonoid, dan steroid dan triterpenoid. Adapun cara kerja dari senyawa flavonoid, yaitu dapat mendenaturasi serta mengkoagulasi protein sehingga dapat merusak dinding sel bakteri, menyebabkan lisis dan kebocoran pada dinding sel bakteri sehingga mampu menghambat pertumbuhan bakteri (Katzung, 2001).

Menurut Sudarwati, E.V (2018) senyawa saponin mempunyai kemampuan sebagai antimikroba yang bersifat bakteriostatik dimana dapat menghambat pertumbuhan bakteri, dan menyebabkan kebocoran pada sel bakteri. Sedangkan senyawa tanin dapat mengkoagulasi protein serta mengkerutkan dinding sel bakteri yang menyebabkan pertumbuhannya dapat terhambat sampai menyebabkan bakteri mati (Nuria, dkk 2009). Senyawa terpenoid mempunyai kemampuan untuk menghambat bakteri, dengan mengganggu permeabilitas dinding sel bakteri sehingga pertumbuhannya menjadi terhambat (Heni \& Zaharah, 2015). Adapun senyawa aktif pada daun pepaya yang telah ditemukan oleh Tutun, (2013) berupa alkaloid karpain dan tocophenol. Alkaloid karpain bekerja dengan merusak inti sel bakteri, dimana kerusakan sel membuat bakteri tidak mampu untuk mengalami metabolisme dan akhirnya membuat lisis. Tocophenol merupakan senyawa fenol yang bekerja dengan memutuskan ikatan peptidoglikan pada dinding sel bakteri, sehingga menyebabkan kerusakan pada membran sel.

\section{Kesimpulan}

Berdasarkan hasil penelitian, maka dapat ditarik kesimpulan yaitu daun dan biji pepaya berpotensi sebagai antibakteri dengan daya antibakteri sedang sampai kuat, yang telah diuji terhadap beberapa bakteri yaitu Escherichia coli, Bacillus subtilis, Pseudomonas aeruginosa, Staphylococcus aureus, dan Salmonella typhi. Senyawa metabolit sekunder yang bersifat sebagai antibakteri yaitu alkaloid, flavonoid dan tanin. Adapun senyawa aktif yang terkandung 
pada daun pepaya yaitu alkaloid karpain dan tocophenol.

\section{Daftar Pustaka}

[1] Ariani, N., Monalisa, M., \& Febrianti, D. R. (2019). Uji aktivitas antibakteri ekstrak biji pepaya (Carica Papaya L.) terhadap pertumbuhan Escherichia coli. JCPS (Journal of Current Pharmaceutical Sciences), 2(2), 160-166.

[2] Gillespie, S. H., \& Bamford, K. B. (2009). At a Glance Mikrobiologi Medis dan Infeksi Edisi Ketiga. Jakarta: Erlangga.

[3] Heni, S. A., \& Zaharah, T. A. (2015). Efektivitas Antibakteri Ekstrak Kulit Batang Belimbing Hutan (Baccaurea angulata Merr.) Terhadap Staphylococcus aureus dan Escherichia coli. Jurnal Kimia Khatulistiwa, 4(1).

[4] Jawetz, M., \& Kedokteran, M. (2005). Edisi 23. Alih Bahasa: Huriwati Hartanto Dkk. Jakarta: EGC.

[5] Katzung, B. G. (2001). Farmakologi: Dasar dan Klinik. Salemba Medika, Jakarta.

[6] Karisma, E. V. (2019). Uji Aktivitas Antibakteri Ekstrak Daun Pepaya (Carica papaya L.) Terhadap Bakteri Escherichia coli dan Staphylococcus aureus. Jurnal Farmasindo, 3(2), 16-20.

[7] Mawan, A. R. et al. (2015). Aktivitas Antibakteri Ekstrak Metanol Kulit Batang Tumbuhan Salam (Syzygium polyanthum) Terhadap pertumbuhan Bakteri Escherchia coli',pp.8-13.

[8] Misna, M., \& Diana, K. (2016). Aktivitas antibakteri ekstrak kulit bawang merah (Allium cepa 1.) terhadap bakteri Staphylococcus aureus. Jurnal Farmasi Galenika (Galenika Journal of Pharmacy)(e-Journal), 2(2), 138-144.

[9] N. Nirosha \& R. Mangalanayaki. (2013). Antibacterial Activity of Leaves and Stem Extract of Carica papaya L. International Journal Of Advances In Pharmacy Biology And Chemistry. Vol 2 (3).

[10] Nuria, M.C., A. Faizatun., dan Sumantri. 2009. Uji Antibakteri Ekstrak Etanol

[11] Daun Jarak Pagar (Jatropha cuircas L) terhadap Bakteri Staphylococcus aureus ATCC 25923, Escherichia coli ATCC 25922, dan Salmonella typhi ATCC 1408. Jurnal Ilmu ilmu Pertanian. 5: 26 - 37.

[12] Nor, T. A., Indriarini, D., \& Koamesah, S. M. J. (2018). Uji aktivitas antibakteri ekstrak etanol daun pepaya (carica papaya L ) terhadap pertumbuhan bakteri Escherichia coli secara in vitro. Cendana Medical Journal (CMJ), 6(3), 327-337.

[13] Purba, R,D. (2001). Analisis Komposisi Alkaloid Daun Handeleum ( Graptophyllum pictum (Linn), Griff) yang Dibudidayakan dengan Taraf Nitrogen yang Berbeda. (Skripsi). Bogor: IPB.

[14] Romadanu, R., Hanggita, S., \& Lestari, S. D. (2014). Pengujian aktivitas antioksidan ekstrak bunga lotus (Nelumbo nucifera). Jurnal FishtecH, 3(1), 1-7.

[15] Roni, A., Maesaroh, M., \& Marliani, L. (2019). Aktivitas antibakteri biji, kulit dan daun pepaya (Carica papaya L.) terhadap bakteri Escherichia coli dan Staphylococcus aureus. Kartika: Jurnal Ilmiah Farmasi, 6(1), 29-33.

[16] Sudarwati, T. P. L., \& Fernanda, M. A. (2018). Aktivitas Antibakteri Daun Pepaya (Carica papaya) Menggunakan Pelarut Etanol Terhadap Bakteri Bacillus subtilis. Journal of Pharmacy and Science, 3(2).

[17] Tambunan, M. L., Sitompul, E., \& Ginting, O. S. B. G. (2018). Perbandingan Aktivitas Antibakteri Ekstrak Etanol dan Ekstrak n-Heksana Biji Pepaya (Carica papaya L.) Terhadap Bakteri Escherichia coli. Jurnal Stikna, 2(1).

[18] Tietze HW. (2002). Terapi Pepaya Sebuah Bentuk Terapi Makanan Yang Aman Dan Murah. Jakarta: PT Prestasi Pustaka Raya.

[19] Tjukup Marnoto, T., Gogot Haryono, G., Dewi Gustinah, D., \& Fendy Artha Putra, F. (2012). Ekstraksi tannin sebagai bahan pewarna alami dari tanaman putrimalu (Mimosa pudica) menggunakan pelarut organik. Reaktor, 14(1), 39-45. 
[20] Torar, G. M. (2017). Uji aktivitas antibakteri ekstrak etanol biji pepaya (Carica papaya L.) terhadap bakteri Pseudomonas aeruginosa dan Staphylococcus aureus. Pharmacon, 6(2).

[21] Tuntun, M. (2016). Uji Efektivitas Ekstrak Daun Pepaya (Carica papaya L.) Terhadap Pertumbuhan Bakteri Escherichia coli dan Staphylococcus aureus. Jurnal Kesehatan, 7(3), 497-502.

[22] Wadapurkar, R. M., Shilpa, M. D., Katti, A. K. S., \& Sulochana, M. B. (2018). In silico drug design for Staphylococcus aureus and development of host-pathogen interaction network. Informatics in Medicine Unlocked, 10, 58-70.

[23] World Health Organization (2017). The top 10 causes of the death. Geneva.

[24] World Health Organization. (2020). WHO Reveals Leading Causes of Death and Disability Worldwide: 2000-2019. Retrieved February, 21, 2021.

[25] Zukhri, S. (2016). Efektifitas Antibakteri Ekstrak Etanol Biji Pepaya (Carica papaya L) Terhadap Bakteri Escherichia coli. Motorik Jurnal Ilmu Kesehatan, 10(20). 